\title{
HUMAN TRAFFICKING IN INDONESIA, THE DIALECTIC OF POVERTY AND CORRUPTION
}

\author{
Evie Ariadne ${ }^{1}$, Benazir Bona Pratamawaty ${ }^{2}$ and Putri Limilia ${ }^{3}$
}

${ }^{1}$ Faculty of Communication, Universitas Padjadjaran, Jl. Raya Bandung-Sumedang KM. 21 Jatinangor, 456363

E-mail: evie@unpad.ac.id ; benazir.bona@unpad.ac.id; p.limilia@unpad.ac.id

\begin{abstract}
Thirteen years of the enactment of Law Number 21 of 2007 concerning the Eradication of the Criminal Act of Trafficking in Persons (TPPO), still cannot free Indonesia from cases of trafficking in persons. Indonesia is not only the main source country in the trafficking process, but is also used as a destination and transit country. And what is very concerning, all provinces (34 provinces) in Indonesia are the origin and destination of trafficking in persons and the victims are mostly experienced by women and children. The most common forms of trafficking are forced labor and sexual exploitation, especially of women, children and boys. They are taken abroad and across international borders without legal travel documents. Usually they are exploited in the fishery and fish processing industries, construction; oil palm plantations, mining and manufacturing. The poverty factor is considered to be the main trigger for prospective Indonesian workers. Another thing is because of natural disasters which are also prone to human trafficking. In addition, endemic corruption among government officials contributes to the vulnerability of trafficking in persons, especially in the travel, hotel and labor recruitment industries. The phenomenon of globalization is one factor in the spread of contemporary (modern) issues that have an impact on human trafficking. Advances in information technology are opportunities for the expansion of crime networks, both nationally and transnationally (across borders). The fact that now the world seems borderless, makes crosscultural social integration happen, where people are free to move without barriers. This causes various modes of crime to emerge, including human trafficking.
\end{abstract}

Key words: human trafficking; poverty; exploitation; globalization; systematic literature review

\section{PERDAGANGAN ORANG DI INDONESIA, DIALEKTIKA ATAS KEMISKINAN DAN KORUPSI}

\begin{abstract}
ABSTRAK. Tiga belas tahun berlakunya Undang-Undang Nomor 21 Tahun 2007 tentang Pemberantasan Tindak Pidana Perdagangan Orang (TPPO), masih belum bisa membebaskan Indonesia dari kasus perdagangan orang. Indonesia tidak hanya sebagai negara sumber utama dalam proses trafficking, tetapi juga digunakan sebagai negara tujuan dan transit. Dan yang sangat memprihatinkan, semua provinsi (34 provinsi) di Indonesia merupakan daerah asal dan tujuan perdagangan orang dan korbannya sebagian besar dialami oleh perempuan dan anak. Bentuk perdagangan yang paling umum adalah kerja paksa dan eksploitasi seksual terutama perempuan, anak-anak dan anak laki-laki. Mereka dibawa ke luar negeri dan melintasi perbatasan internasional tanpa dokumen perjalanan yang legal. Biasanya mereka dieksploitasi di sektor perikanan dan industri pengolahan ikan, konstruksi; perkebunan kelapa sawit, pertambangan dan manufaktur. Faktor kemiskinan dinilai menjadi pemicu utama calon tenaga kerja Indonesia. Hal lainnya karena bencana alam yang juga rawan perdagangan manusia. Selain itu, korupsi endemik di kalangan pejabat pemerintah berkontribusi pada kerentanan perdagangan orang, terutama di industri perjalanan, hotel, dan perekrutan tenaga kerja. Fenomena globalisasi merupakan salah satu faktor penyebaran isu kontemporer (modern) yang berdampak pada perdagangan manusia. Kemajuan teknologi informasi, merupakan peluang perluasan jaringan kejahatan, baik nasional maupun transnasional (lintas batas). Fakta bahwa kini dunia seolah tanpa batas, membuat terjadinya integrasi sosial lintas budaya, dimana orang bebas bergerak tanpa hambatan. Hal ini menyebabkan berbagai modus kejahatan bermunculan, termasuk perdagangan manusia.
\end{abstract}

Kata kunci: Human Trafficking; Kemiskinan; Eksploitasi; Globalisasi; Korupsi.

\section{INTRODUCTION}

After thirteen a long time of execution of Law Number 21 of 2007 concerning the Destruction of the Wrongdoing of Trafficking in People, appear still incapable to discharge Indonesia from cases of trafficking in people. Indonesia isn't as it were a major source nation within the human trafficking handle, but is additionally utilized as a goal and travel nation. In Indonesia, the foremost common shapes of trafficking are for constrained work and sexual misuse as ladies, children and men are moved inside the nation and over worldwide borders. Every province in Indonesia could be a goal of root for trafficking in people, and the larger part of casualties are ladies and children (Utami, 2019). Based on the 2018 Criminal Investigation Report the national police, Kepolisian Republik Indonesia (POLRI), the victim 70 percent of the 297 victims were women, with details of 190 adult women and 18 girls, while the rest were men and boys (Kepolisian Negara Republik Indonesia, 2018). Meanwhile, the Ministry 
of Foreign Affairs reported that in 2018 it handled 162 cases of Indonesian citizens (WNI) victims of TIP abroad Middle East 74 people, East Asia and Southeast Asia 47 people, Africa 39 people, South Asia and Central Asia 1 person, and America. North and Central America 1 person (Kementerian Pemberdayaan Perempuan dan Perlindungan Anak, 2019). Of the total cases, 88 cases were resolved (54\%) and 74 cases were being processed (46\%).

The information over affirms the Yearly Report on Trafficking in People arranged by the Joined together States Government office for 2019, which states that the Indonesian government has not completely met the least guidelines for the destruction of trafficking in people. Indeed in spite of the fact that within the report, the Indonesian government is still acknowledged for having made and is making noteworthy endeavors to create it happen. For example, the Government of Indonesia is seen as appearing distant better in general advancement in exertion when compared to the past announcing period, which keeps Indonesia within the level 2 category.

The report clarifies, the endeavors made by the Indonesian government incorporate shaping 13 assignment powers for law authorization of trafficking in people and three inter-agency assignment powers at the territorial and locale levels, as well as proceeding to form and disseminate human trafficking socialization materials to extend open awareness. In expansion, the government issued a ecclesiastical control requiring nearby governments to incorporate the annihilation of the Wrong doing of Trafficking in People (TPPO) in their approach needs and comprehensive security for Indonesian citizens overseas, counting casualties of human trafficking. The government too issued a direction that permits the Witness and Casualty Assurance Office (LPSK) to incorporate compensation installments as portion of discipline to culprits some time recently or after choices on cases of trafficking in people and other violations and started defining actualizing controls for the 2017 Indonesian Transient Laborers Assurance Act (International Organization for Migration, 2016).

However, agreeing to the report, the government has not met least benchmarks in a few key ranges, among others this may be seen from the diminishing number of examinations, arraignments and choices. The inclusion of officials in human trafficking violations still must be considered, and in spite of the fact that the government reports on continuous examinations, the government has not detailed any charges or sentences against officers suspected of being included in TIP. The report too expressed that the Indonesian government had collaborated with universal organizations to create casualty identification procedures but had not completed them amid the announcing period which the nonattendance of such methods ruined distinguishing proof of casualties as a entire and male casualties in particular. Another thing, the Indonesian government's recovery administrations for taking care of Trafficking in People are considered inadequately. Amid the detailing period, five Injury Middle Security Homes (RPTC) level the master

The emergence of trafficking in persons often occurs in vulnerable groups of society, especially women and children, because in Indonesian society, women in the family structure are often not the head of the household who have the power to make strategic decisions (Bryant \& Landman, 2020)there were an estimated 40.3 million victims of modern slavery in the world, more than were enslaved during the Transatlantic Slave Trade. Since the adoption of the 2000 UN Trafficking Protocol, numerous efforts from inter-governmental agencies, governmental agencies, international nongovernmental organizations (INGOs. Meanwhile, the poor economic conditions of the family force women and children to look for work, and without any choice they are trapped in the trafficking network.

The legitimate angle is still tricky, where the 2007 Law on the Annihilation of the Wrongdoing of Trafficking in People is conflicting with worldwide law and still contains conditions for the utilize of constrain, extortion or constraint to legitimize the event of child sex trafficking violations.

In our opinion, the core problem of Human Trafficking in Indonesia is not only as described above, but also regarding communication between related institutions in dealing with TIP. Therefore, it is necessary to first identify what are the problems that occur in TIP.

This general description of human trafficking and the fact that it is a need to enhance the effective communication between many institutions, has encouraged researchers to examine more deeply, especially from the perspective of communication, given that so many institutions and organizations are government stakeholders in the effort to deal with trafficking in persons. So the research question from this literature review is: what and how is the problem of TIP in Indonesia?

This article is the initial part of a series ofresearch entitled "SDG Acceleration through Optimizing Government Communication and the Role of Civil Society in Resolving Human Trafficking Problems in Indonesia". The research, with a grant from the 
Higher Education which is planned to take place in three years starting in 2020, was forced to undergo a design change because the situation suddenly became difficult due to the Covid-19 pandemic that hit almost all countries in the world. The main obstacle occurred at the data collection stage which did not allow researchers to go to the field directly, so that the data collection method for the first year of this study had to be adjusted by minimizing direct contact with informants in the field. In a situation where everyone has to "work from home" and maintain "social distancing", the research team decided that data collection was carried out using two methods, namely virtual content analysis and Systematic Literature Review. This paper is the result of a literature study using the keywords "human trafficking, civil society, and Government Communication".

\section{METHOD}

This think about employments the efficient Writing audit (SLR) strategy, which may be a inquire about strategy to distinguish, assess and decipher all pertinent investigate comes about related to particular inquire about questions, certain subjects, or marvels of concern (Kitchenham, 2004; Siswanto, 2010). In differentiate to person consider, which could be a form of essential consider, orderly audit may be a auxiliary consider which is exceptionally valuable for synthesizing different significant inquire about comes about, so that the realities displayed to approach creators are more comprehensive and adjusted.

\section{RESULTS AND DISCUSSION}

In this segment, the creator portrays the comes about of a writing audit that incorporates the recognizable proof of the issues of TIP in Indonesia, which is able at that point be analyzed, what kind of government communication demonstrate is satisfactory to fathom this TIP issue.

The Trafficking Casualties Security Act of 2000 , as revised (TVPA), characterizes "serious shapes of trafficking in people" as: $\mathrm{n}$ sex trafficking in which a commercial sex act is actuated by drive, extortion, or impelling, or in which the individual is initiated to perform such an act has not achieved 18 a long time of age; or $\mathrm{n}$ the enlistment, harboring, transportation, arrangement, or getting of a individual for work or administrations, through the utilize of drive, extortion, or constraint for the reason of subjection to automatic bondage, peonage, obligation servitude, or subjugation . A casualty require not be physically transported from one area to another for the wrongdoing to drop inside this definition. Trafficking in People agreeing to the Law of the Republic of Indonesia Number 21 of 2007 Article 1 is: "the act of enlisting, transporting, holding, sending, exchanging, or tolerating a individual with dangers of savagery, the utilize of constrain, capturing, restriction, fraud, extortion, mishandle of control or position. defenseless, obligation subjugation".

As detailed by the Secretariat of the TPPO Assignment Constrain in 2018, amid the final five a long time, traffickers have abused household and outside casualties in Indonesia, and the culprits have moreover abused Indonesian casualties overseas. All areas (34 areas) in Indonesia are the root and goal ranges of human trafficking. NGOs appraise deceitful enlistment organizations and subagents are capable for more than half of Indonesian trafficking cases that happen overseas. In expansion, a few companies hold personality reports and utilize dangers of savagery to keep vagrant laborers from proceeding to work coercively. Sex traffickers abuse Indonesian ladies and young ladies, particularly in Malaysia, Taiwan and the Center East.

In Indonesia, work traffickers abuse ladies, men and children in angling (Hidayat, 2015), angle handling and development; on manors, counting oil palm manors, mining and fabricating. Indonesian anglers who work on Taiwan, Thailand, Malaysia, and the Philippines hailed angling vessels working in Indonesian, Thai, Sri Lanka, Mauritius and Indian waters, detailed watercraft captains of mishandle that cleared out significant impacts, constrained work, unpaid compensation, and, in a few cases, kill. Each year, there are more than 7,000 Indonesian anglers who enter and take off outside vessels secured in Cape Town, South Africa, and are detailed to be encountering destitute working conditions, particularly on pontoons possessed by Taiwanese, Korean and Japanese citizens.

Like the two sides of the coin, on the one hand, workers have a positive impact on the growth of the country's foreign exchange, so they are given the title "Foreign Exchange Hero" but on the other hand they are victims of human trafficking.

\section{Human Trafficking Operand Mode}

In the following section, the authors describe several examples of trafficking cases that attracted enough media attention that occurred in July 2019, namely the case of Chinese "Order Marriage" with Indonesian citizens. The Indonesian Migrant Workers Union (SBMI) in mid-July succeeded in repatriating two suspected victims of trafficking with 
matchmaking methods. They married a Chinese man with the lure of a sum of money and the lie that the husband was rich. But in fact, these women are subjected to torture and forced labor without being paid any wages. According to SBMI, there are 26 cases of ordered marriages. A total of 14 people came from West Kalimantan, seven people from West Java, two from Tangerang, one from East Java, one from Central Java, and one from DKI Jakarta.

Reacting to the arrange marriage case to China, the Service of Remote Undertakings of the Republic of Indonesia expressed that it cannot work alone, within the sense that this issue cannot be settled downstream by the service of remote undertakings, but must be settled from the upstream.

That is why, the Minister of Foreign Affairs himself went to Pontianak to provide understanding to all stakeholders such as the local government, the police, local government agencies so that they could jointly resolve this issue (Khotimah, 2019).

The complexity of the mail order bride case requires comprehensive handling. It is very important to break the chain of order bride cases through central and regional coordination - upstream and downstream, "Foreign Minister Retno emphasized in her meeting with the ranks of the West Kalimantan Provincial Government.

The Arrange Bride mode contrasts from "Pretense marriage" which ordinarily includes a situation in which two people donate their assent and concur to wed subject to conditions that incorporate an trade of benefits, budgetary or something else, in arrange for one party to get changeless home within the other nation. This hone is diverse from constrained marriage, which is marriage that takes put without the complete assent and is free of one or both individuals into a marriage. Specialists have as of late highlighted human trafficking within the setting of "fake marriage" as an progressively common drift in Europe.

Different scholar thinks about and ventures from other teach, NGOs, and universal organizations have endeavored to get it and analyze the interface between trafficking and fake marriage in Europe. One well-known EU extend created the express "exploitative pretense marriage" to depict a fake marriage that includes all shapes of misuse, counting human trafficking. The extend found that exploitative pretense relational unions speak to all three components of the wrongdoing of trafficking in people. In selecting casualties through pretense relational unions, traffickers utilize individual contacts, counting familyindividuals and companions, and social media such as Facebook, web dating destinations, and notices, to bait potential casualties with guarantees of fake cash, deceiving work offers or openings for extortion. Traffickers more often than not, but not only, target ladies as potential casualties, regularly from destitute foundations, with negligible instruction, or from powerless populaces or destitute communities, such as Roma. Shapes of misuse extend from sex trafficking to residential servitude to constrained criminal movement. These ponders assist appear that exploitative pretense marriage plans are more likely to be carried out by organized wrongdoing syndicates that moreover lock in in other shapes of abuse.

In addition to the mail order bride case, there is also a case of trafficking in the form of the sale of Indonesian domestic workers (TKI) household assistants, which are advertised on the platform for buying and selling new and used goods which is central in Singapore, namely Carousell. On that page, we found an account with the title@ maid. recruitment which transferred a few profiles of Indonesian transient specialists, a few profiles have indeed gotten a sign that they have been sold. At the request of the Indonesian Ministry of Foreign Affairs, the Singapore Ministry of Manpower has requested that the sale be removed from the Carousel website for violating the Manpower Act and subject to sanctions in the form of a fine of 80 thousand Singapore dollars and or up to two years imprisonment (CNN Indonesia, 2018). In this case, the Carousel management itself stated that human trafficking was not permitted on its website, because the company guidelines contained a strict prohibition on displaying or sharing personal data.

The last case, which was quite shocking, occurred at the beginning of the Covid-19 pandemic, where a video circulated in December 2019 and March 2020, three Indonesian crew members died on board Long Xin 629 and Long Xin 604 while sailing in the Pacific Ocean. The captain of the ship claimed the decision to dispose of the body was due to death caused by an infectious disease and with the consent of all the crew members. The Embassy of the Republic of Indonesia (KBRI) in Beijing has submitted a diplomatic note asking for clarification of the case. In an explanation to the Indonesian Embassy in Beijing, the Chinese Ministry of Foreign Affairs stated that the ban was carried out in accordance with international maritime regulations to maintain the health of other crew members (figure 1).

Bareskrim data shows that at least nine routes or routes of human trafficking or trafficking in persons have been identified by the Police, in this case the Criminal Investigation Agency (Bareskrim). 
Malaysia and Singapore are the two countries that are used as transit locations and then proceed to Middle Eastern countries.

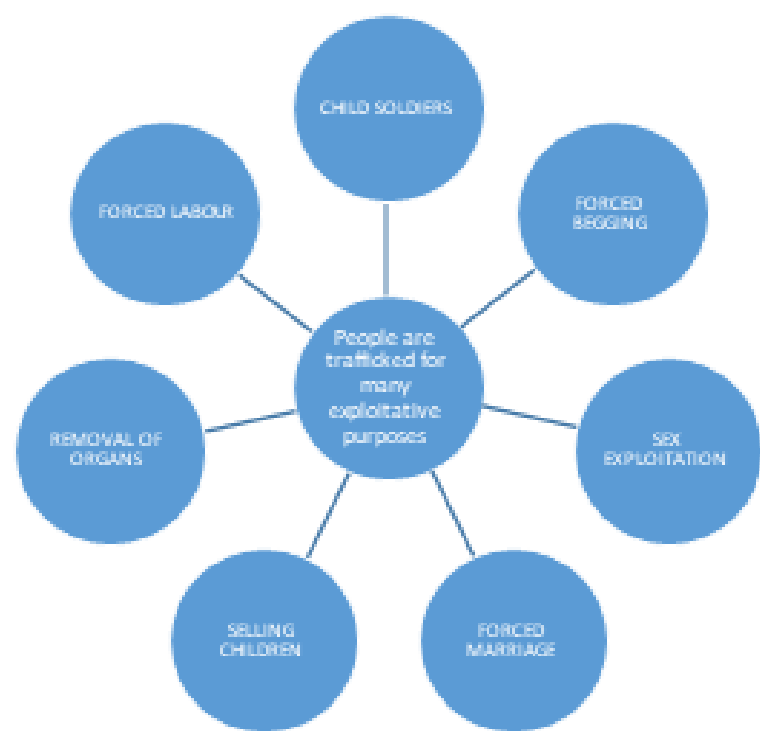

Source: Trafficking In Persons Report June 2019, Departement Of State USA Figure 1. The Aim Of Human Trafficking

\section{Factors Causing Human Trafficking}

By identifying these nine pathways, it appears that the problem of trafficking in persons is also an impact of the globalization phenomenon. Advances in information and communication technology provide opportunities for the expansion of crime networks, both national and transnational (across borders). Globalization has obscured national boundaries and made a discernment of a borderless world, which permits individuals to move around unreservedly without any deterrents. Globalization as a change of advance has moreover driven to different social changes such as destitution, unemployment and wrongdoing which have brought about within the spread of universal human trafficking"

Phil Williams, Chief of Worldwide Security Thinks about, College of Pittsburgh, in a talk of "the blast of transnational wrongdoing in a globalized world" said: "Transnational offenders have been one of the greatest recipients of globalization. Globalization encourages worldwide exchange but too increments the trouble. of directing worldwide exchange, he says; traffickers and runners have abused this. Williams includes that globalization has expanded imbalance around the globe, which "its troublesome impact has really caused people to ought to go into organized wrongdoing and work in unlawful markets as adapting instruments"

There's a all inclusive perspective behind the human trafficking issue experienced by nations around the world. The reasons are: destitution (Agustinanto et al., 2013), globalization (Absor,
2018; Daniel, Mulyana, \& Wibhawa, 2017), the sex tourism industry, women's rights, and common worldwide instruction levels. Destitution is one of the most factors that energize individuals to do anything to induce out of their confinements. To get it how this widespread issue acts as a cause, it is basic to see at three specific points of dejection: the supply side, the request side, and the interaction between these two strengths. The supply side is affected by destitution variables experienced by people (restricted offices and get to to life necessities). The request side alludes to commercial businesses or exercises that depend on destitution as a product (people are exchanged illicitly) with the point of keeping up a benefit or benefit. The larger part of different sees of teach or organizations state that the most calculate and root cause of human trafficking is affected by the supply side as a result of destitution.

The irony is that human trafficking, which contradicts human values, is a trade sector that is very profitable economically. This transnational action and crime is estimated to be able to generate profits of around 32 billion US dollars per year. The value of the profits it gets makes human trafficking in the third position behind narcotics smuggling and arms trafficking.

Human trafficking is a very complex issue. The complexity of the problem is related to the involvement of many actors and interests as well as its very broad root causes, there are at least five factors that can generally be identified in the driving and pulling factors of human trafficking as follows:

1. economic factors (Harkrisnowo, 2003; Sapardjaja, 2003), high levels of unemployment and poverty, limited employment the desire to get out of poverty and improve the standard of living welfare often ultimately results in no other choice to fall into human trafficking.

2. a slow population administration system. Until now, the Indonesian population system has not fully used the national online system. The manual system which is generally still used in many parts of Indonesia often facilitates duplication or falsification of a person's identity for trafficking purposes.

3. Third is the abuse of office and rampant mental corruption. In various chains of human trafficking activities, it is not uncommon for officials to be involved, namely by facilitating or permitting the crime. Village or sub-district officials, for example, want to issue a real identity but fake asphalt for potential victims of human trafficking who are still minors in exchange for a certain amount of money. 
4. Fourth is the lack of strict supervision of companies placing labour migrants abroad, starting from the recruitment process for holding workers to placing them. Weak supervision often causes Indonesian workers abroad to find jobs that are not in accordance with the work contract, even worse luck befalls them. because it is traded

5. The fifth is the demand for foreign labor market

\section{Innovation: Portion Of The Issue}

Using innovation for communications and exchanges among traffickers. "Traffickers in [a few] nations are not uneducated, "paan-chewing" men, but carry cell phones, video cameras, and talk refined English instep, permitting them to abuse ladies and children more effectively and viably than ever before". Traffickers are as assorted as the nations in which they work. A few are ineffectively taught people who have few aptitudes but those they learn in wrongdoing, whereas others are regarded individuals of the community as well as covert individuals of well resourced, exceedingly advanced wrongdoing syndicates who can manage to stay on the peak of mechanical progresses. Notwithstanding of which conclusion of the 'sophistication' range traffickers are working and regardless of where within the world they are committing their wrongdoings, all of them are profiting in their criminal exercises through progresses in innovation which make it quicker, less demanding cheaper (and eventually more beneficial) to conduct exchanges.

Sorts of Communication Innovation, there are different shapes of innovation which offer organized traffickers fields in which to assemble transmit communications and unlawful fabric to each other. A few of them incorporate; - Newsgroups: locales for trade of data. - Web message and bulletin sheets: trade of data; comparative to newsgroups but can be private and watchword secured. - Websites and look motors $\bullet$ Chat rooms: genuine time communication; no messages are chronicled or put away, and no log records are kept up. $\bullet$ Record Exchange Convention (FTP): successful record trade on the web, permits clients coordinate get to another's computer difficult drive to transfer and download files. Peer to Peer systems and record swapping programs: utilized to share illicit fabric by finding and downloading records on online systems without clearing out traceable transmissions. Encryption: can be utilized to camouflage the substance of files. Portable web frameworks.

\section{Technology: Portion Of The Arrangement}

It is outlandish to stop the progress of innovation or to stem the tide of its multiplication around the world, and to do so would be an colossal misfortune to the lion's share of individuals who advantage in authentic ways from its utilize. In battling transnational composed wrongdoing which is encouraged by the utilize of innovation, instead of quelling innovation, it gets to be vital to saddle its potential to meddled with organized criminal exercises and to combat trafficking and help its casualties. There are various illustrations around the world of this being done. Participation is key to endeavors to explore, interrupt and indict traffickers; typically all the more so presently with the increasing speed of globalized innovation. The universal versatility of wrongdoers and their utilize of progressed innovation makes it more vital than ever that law masters and legal specialists arrange their reactions to be able to take after wrongdoings and offenders over borders.

\section{The Part Of The Media}

The media is an vital vehicle through which data can be gotten and traded. In fact these days open information approximately remote occasions, counting war and universal emergencies, depends intensely on mass media. As the so-called 'fourth estate', the media is additionally a effective instrument in impacting open supposition and raising mindfulness around an issue. With such control, be that as it may, comes also the obligation to supply precise data to the open on a given issue and at the same time to guarantee the assurance of person sources from any hurt as a result of data divulgence. The media frequently makes or reinforces cliché and negative pictures around individuals. Within the setting of human trafficking, besides, when writers wish to tell a story and put a confront to a casualty, they run the peril - but regularly inadvertedly of victimizing them encourage. Casualties are regularly delineated as naïve, and socio-economic issues are diminished to depictions of individual injuries. Besides, casualties may well be displayed in an excessively compassionate way, befuddling sensitivity (feel sorry for) with genuine compassion (understanding) for the setting and reality of their encounters. Media substance is created through prepare in which a assortment of variables play a part. These findings in line with previous research which argue that the victim frequently portrayed as minors (Sanford, Martínez, \& Weitzer, 2016).

\section{The Part of Debasement in Trafficking}

In Persons Trafficking in people and debasement are closely connected criminal exercises, whose 
interrelation is as often as possible alluded to in worldwide fora. However, the relationship between the two marvels, and the real affect of debasement on trafficking in people, are for the most part dismissed within the advancement and execution of anti-human trafficking arrangements and measures. This need of consideration may significantly weaken activities to combat trafficking in people and avoid the customization of reactions as required. As it were after recognizing the presence and the effects of debasement within the setting of human trafficking, can the challenges postured by it be met. It is hence imperative to look at how debasement plays a part in human trafficking and really contributes to the development of the phenomenon.

\section{Inter Institutional relations}

In 2016, the Indonesian Government through seven services and tall state educate introduced a Reminder of Understanding related to the issue of human trafficking, with the point of making a national referral instrument in taking care of Indonesian citizens of TIP casualties overseas, so that casualties and existing cases can be taken care of more viably. ideal. This assention was started to bargain with the criminal act of trafficking in people (TPPO) and ensure Indonesian citizens (WNI) overseas. The seven services and tall teach incorporate the Service of Outside Undertakings, the Service of Ladies Strengthening and Child Assurance, the Service of Law and Human Rights, the Service of Social Undertakings, the Indonesian Police, the Indonesian Prosecutor's Office, and the National Office for Situation and Assurance of Indonesian Laborers (BNP2TKI). Through the marking of the reminder of understanding, the seven services / organizations concurred to extend the viability of participation and coordination within the setting of annihilating trafficking in people including Indonesian citizens overseas as casualties.

The Memorandum of Understanding contains various forms of cooperation that will be carried out by the seven ministries / agencies related to five fields, namely joint identification, victim handling, joint prevention activities, data exchange and capacity building of human resources.

\section{CONCLUSION}

The comes about of mapping the issue of TIP in Indonesia appear numerous things that got to be watched by approach creators. The distinguished issues incorporate, Human Trafficking Operand
Mode, Components Causing Human Trafficking, the part of innovation (which partitioned in two viewpoint, Innovation Portion Of The Issue and Innovation: Portion Of The Arrangement), The Part of Debasement in Trafficking in People, InterInstitutional Relations, and The Part Of The Media. Efforts to bargain with human trafficking require different synchronous and synergistic endeavors, organization fortifying, framework fortifying, law authorization, coordination and cross-sector participation. In expansion, nearby governments and communities play an vital part in giving starting data to law authorities with respect to signs of TIP. On the other hand, due to the deficiently capacity and capability of the partners within the locales, the stakeholders' understanding of the arrangements to handle trafficking in people is still mixed.

\section{ACKNOWLEDGMENTS}

The author would like to thank the various parties who have contributed to this research related to human trafficking, especially to the Directorate General of Higher Education, Ministry of National Education, who have funded this research through the PDUPT grant scheme. We are also grateful to Padjadjaran University for providing various facilities for us to carry out this research, especially to the Faculty of Communication Sciences Unpad which technically helped provide many solutions related to the dissemination of research results.

\section{REFERENCES}

Absor, M.U. (2018). Human Trafficking and the Challenges for Social Development in Indonesia. Jurnal Pemikiran Sosiologi, 5(1), 37. https://doi.org/10.22146/jps.v5i1.35401

Agustinanto, F., Davis, J., Hamim, A., Inggas, K. I., Jahja, R., Mahri, F. \& Wahyuningrum. (2013). Trafficking Of Women And Children In Indonesia. Journal of Petrology. https://doi. org/10.1017/CBO9781107415324.004

Bryant, K. \& Landman, T. (2020). Combatting Human Trafficking since Palermo: What Do We Know about What Works? Journal of Human Trafficking, 6(2), 119-140. https:// doi.org/10.1080/23322705.2020.1690097

CNN Indonesia. (2018, September 16). Kemenlu Minta Singapura Usut Penjualan TKI via Daring. Retrieved October 30, 2021, from https://www.cnnindonesia.com/ internasional/20180916164048-106-330622/ 
kemenlu-minta-singapura-usut-penjualan-tkivia-daring

Daniel, E. S. R., Mulyana, N., \& Wibhawa, B. (2017). Human Trafficking Di Nusa Tenggara Timur. Share : Social Work Journal, 7(1), 21. https:// doi.org/10.24198/share.v7i1.13808

Harkrisnowo, H. (2003). Laporan Perdagangan Manusia di Indonesia Daftar isi. Jakarta.

Hidayat, R. (2015). Kajian Bentuk- Bentuk Eksploitasi Seks Komersial Anak Di Lingkungan Wisata Provinsi Sulawesi Utara. Sosiohumaniora, 17(3), 237. https://doi. org/10.24198/sosiohumaniora.v17i3.8342

International Organization for Migration. (2016). Laporan Mengenai Perdagangan Orang, Pekerja Paksa, Dan Kejahatan Perikanan Dalam Industri Perikanan Di Indonesia. Jakarta. Retrieved from https://kkp.go.id/ wp-content/uploads/2017/01/8-IOM_KKP_ Conventry_INDO_hires-min.pdf

Kementerian Pemberdayaan Perempuan dan Perlindungan Anak. (2019, October 15). Sinergi Seluruh Elemen Untuk Bersama Berantas Tppo. Retrieved October 30, 2021, from https://kemenpppa.go.id/index.php/ page/read/29/2369/sinergi-seluruh-elemenuntuk-bersama-berantas-tppo

Kepolisian Negara Republik Indonesia. (2018). Laporan Analisa Dan Evaluasi Data Kriminalitas Tindak Pidana Umum. Kepulauan Riau. Retrieved from http://kepri. polri.go.id/pid/wp-content/uploads/2018/08/ LAPBUL-DITRESKRIMUM-BULANJUNI-2018.pdf

Khotimah, S. (2019, July 26). Banyak WNI Jadi Korban, Menlu Retno Akan Putus Mata Rantai Pengantin Pesanan - Global Liputan6. com. Retrieved October 30, 2021, from https:// www.liputan6.com/global/read/4022339/ banyak-wni-jadi-korban-menlu-retno-akanputus-mata-rantai-pengantin-pesanan

Kitchenham, B. (2004). Procedures for performing systematic reviews. Keele, UK, Keele University, 33(2004), 1-26.

Sanford, R., Martínez, D.E. \& Weitzer, R. (2016). Framing Human Trafficking: A Content Analysis of Recent U.S. Newspaper Articles. Journal of Human Trafficking, 2(2), 139-155. https://doi.org/10.1080/23322705.2015.1107 341

Sapardjaja, K.E. (2003). Trafficking Perempuan dan Anak di Jawa Barat. Sosiohumaniora, 5(2), 131-147.

Siswanto. (2010). Systematic Review Sebagai Metode Penelitian Untuk Mensintesis HasilHasil Penelitian (Sebuah Pengantar). Buletin Penelitian Sistem Kesehatan, 13(4), 326-333.

Utami, P.N. (2019). Penanganan Kasus Tindak Pidana Perdagangan Orang Oleh Pemerintah Provinsi Nusa Tenggara Timur. Jurnal HAM 10(2), 195-216. 